\title{
FILM DOKUMENTER SENI LUKIS WAYANG KAMASAN KLUNGKUNG BALI
}

\author{
I Kadek Evry Pranata ${ }^{1}$, I Gede Partha Sindu ${ }^{2}$, I Made Putrama ${ }^{3}$ \\ Program Studi Pendidikan Teknik Informatika, \\ Universitas Pendidikan Ganesha \\ Singaraja \\ e-mail:evrypranata75@gmail.com ${ }^{1}$, partha.sindu@undiksha.ac.id ${ }^{2}$, made.putrama@undiksha.ac..id ${ }^{3}$
}

\begin{abstract}
Abstrak
Penelitian ini bertujuan untuk (1) menghasilkan rancangan dan mengimplementasikan hasil rancangan pengembangan Film Dokumenter Seni Lukis Wayang Kamasan. (2) mengetahui respon masyarakat Bali khususnya masyarakat Desa Kamasan terhadap hasil akhir Film Dokumenter Seni Lukis Wayang Kamasan. Jenis penelitian yang digunakan dalam penelitian ini adalah penelitian dan pengembangan dengan model cyclic strategy. Film dokumenter ini diimplementasikan dengan menggunakan aplikasi Adobe Premiere Pro CC 2018 dalam proses video editing, Adobe After Effects CC 2018 untuk pembuatan video animasi, Adobe Audition CC 2018 dalam proses sound editing, serta Adobe Photoshop CC 2018 untuk pembuatan desain keperluan film dokumenter.Hasil penelitian menunjukkan bahwa Film Dokumenter Seni Lukis Wayang Kamasan Klungkung Bali berdasarkan uji ahli isi, dan uji ahli film dokumenter memperoleh rata-rata persentase yaitu $97.16 \%$ dengan tingkat pencapaian "Sangat Baik". Uji respon penonton untuk film dokumenter ini rata-rata persentase yaitu $91.18 \%$ dengan tingkat pencapaian "Baik". Kesimpulan yang didapatkan yaitu Film Dokumenter Seni Lukis Wayang Kamasan Klungkung Bali sudah sangat baik dan bisa digunakan sebagai media informasi sejarah seni lukis wayang kamasan.
\end{abstract}

Kata kunci : Seni Lukis Wayang Kamasan, Desa Kamasan Klungkung, Film Dokumenter, Cyclic Strategy.

\section{Abstract}

This study aims to (1) produce a design and implement the results of the design of the development of the Kamasan Puppet Painting Documentary Film. (2) knowing the response of Balinese people, especially the people of Kamasan Village to the final results of the Kamasan Puppet Painting Documentary Film. The type of research used in this study is research and development with a cyclic strategy model. This documentary film is implemented using the Adobe Premiere Pro CC 2018 application in the process of video editing, Adobe After Effects CC 2018 for making animated videos, Adobe Audition CC 2018 in the sound editing process, and Adobe Photoshop CC 2018 for making documentary design needs. The results of the study showed that the Klungkung Balinese Wayang Documentary Film Documentary based on content expert test, and documentary film expert test obtained an average percentage of $97.16 \%$ with a level of achievement of "Very Good". Test the audience response for this documentary film with an average percentage of $91.18 \%$ with a level of achievement of "Very Good". The conclusions obtained were the documentary documentary of Bali's Kamasan Klungkung Puppet Artwork which was very good and could be used as a medium for information on the history of Kamasan puppet painting.

Keywords: Kamasan Puppet Painting, Kamasan Klungkung Village, Documentary Film, Cyclic Strategy. 


\section{PENDAHULUAN}

Budaya Indonesia memiliki jenis dan warna yang sangat beragam, salah satunya budaya Bali yang memiliki bentuk-bentuk kesenian yang amat kaya. Kebudayaan Bali telah ada sejak zaman kuno dan masih dapat dinikmati oleh masyarakat hingga kini. Salah satu hasil kebudayaan Bali yang masih dapat dinikmati hingga saat ini yaitu seni lukis bali klasik. Kelebihan seni lukis Bali klasik adalah sebagai salah satu cabang seni klasik Indonesia yang masih bertahan, tumbuh, dan berkembang hingga saat ini. Lukisan merupakan salah satu hasil dari sebuah seni yang memiliki keindahan serta memiliki makna tersendiri dari si pembuat. Setiap manusia memiliki sudut pandang yang berbeda di dalam menjalani hidup ini. Begitu pula saat kita membuat suatu lukisan, masing-masing memiliki sudut pandang yang berbeda-beda. Perbedaan sudut pandang dapat dipengaruhi oleh suasana, waktu, dan kondisi geografis. Jenis-jenis lukisan pun banyak bisa kita temui di berbagai daerah. Perbedaanperbedaan dari segi bahan-bahan, alat-alat dan teknik pembuatan suatu lukisan menghasilkan karakteristik yang berbeda. Ragam seni lukis pun sangat di pengaruhi oleh budaya masing-masing daerah [1] Sehingga setiap daerah mempunyai keunikan tersendiri dan dapat dijadikan sebuah ciri khas suatu daerah, seperti Desa Kamasan.

Seni Lukis Wayang Kamasan adalah salah satu bentuk karya seni klasik yang berawal pada abad ke-17 dan dianggap penting dalam kebudayaan Bali. Sementara karya seni ini tidak dapat dipisahkan dari nilai keagamaan, terutama nilai ritual. Banyak aspek yang berkaitan dengan keberadaan seni Lukis Wayang Kamasan, diantaranya adalah aspek filosofi, spiritual, teknis, ekonomi, sosial dan budaya. Diantara berbagai aspek tersebut, khususnya aspek spiritual-kultural merupakan aspek yang menonjol pada Lukisan Wayang Kamasan, seperti menunjukkan kehidupan yang baik dan buruk. Melalui pengabdian tersebut maka diwujudkan lukisan kisah-kisah wayang sebagai bentuk keterkaitan dengan ajaranajaran agama Hindu Bali. Pada umumnya, cerita-cerita yang digambarkan mengandung nilai filosofis agama Hindhu dan budaya Bali, seperti Ramayana, Mahabharata, Sutasoma, Panji, Lelintangan dan lain-lain. Oleh karena itu, lukisan Kamasan atau Wayang Kamasan dapat dikatakan agak tua umurnya dari konteks sejarahnya yang hingga sekarang masih nampak utuh. [2] Bukti nyata seni Lukis Wayang Kamasan ini dapat kita lihat pada lukisan di gedung Kertha Gosa yang dibangun sejak zaman kerajaan Klungkung. Lukisan-lukisan tersebut bercerita tentang perjalanan Bhima ke Swarga Loka, Diah Tantri, Sang Garuda mencari Amerta dan Palelindon. Keunikan seni lukis wayang kamasan masih tergolong tradisional, yaitu menggunakan bambu untuk menjadi kuas dan yip (lidi ijuk dari pohon aren) untuk menjadi pena, dan untuk pewarnanya masih menggunakan bahan alami dari tumbuhtumbuhan.

Berdasarkan wawancara dengan I Nyoman Mandra dalam perkembangan untuk regenerasi muda di Desa Kamasan sulit untuk mencari generasi yang mau untuk meneruskan tradisi melukis Wayang Kamasan, karena selain perkembangan zaman dimana anak-anak sekarang lebih suka melakukan aktivitas belajar ataupun bermain dengan benda-benda yang berbau teknologi seperti komputer, gadget, dan lainlain. Padahal dengan melukis kita dapat memiliki kebermanfaatan terutama kreativitas bagi generasi muda. Disamping itu juga kurikulum di sekolah yang begitu padat sehingga anak-anak di Desa kamasan tidak memiliki waktu untuk belajar melukis Wayang Kamasan. Berbanding terbalik dengan dulu, bapak I Nyoman Mantra sendiri memiliki banyak murid atau anak didik untuk belajar melukis Wayang Kamasan. Eksistensi tradisi ini bisa terjaga dengan menumbuhkan kesadaran masyarakat akan kekayaan budaya yang dimiliki. Warisan yang adiluhung seperti lukis wayang kamasan menjadi perhatian khusus bagi pemerintah pada khususnya untuk melestarikanya. Meski telah mendapatkan perhatian dari pemerintah, seiring dengan perkembangan jaman sudah semestinya semua hal yang berkaitan dengan Lukis Wayang Kamasan ini harus selalu menjadi perhatian khusus baik dari pemerintah atau masyarakat. [3] 
Film dokumenter adalah film yang berhubungan dengan orang-orang, binatang, tokoh, peristiwa dan lokasi yang nyata. film dokumenter tidak menciptakan suatu peristiwa atau kejadian, namun merekam peristiwa yang sungguh-sungguh terjadi atau otentik. Film dokumenter dapat digunakan untuk berbagai macam maksud dan tujuan seperti: informasi atau berita, biografi, pengetahuan, pendidikan, sosial, ekonomi, politik (propaganda). Dalam menyajikan faktanya film dokumenter dapat menggunakan metode merekam langsung pada saat kejadian tersebut benar-benar terjadi, dapat juga menggunakan metode merekontruksi ulang sebuah peristiwa yang terjadi. [4]

Dasar pemikiran diatas menghasilkan ide untuk melestarikan tradisi melukis Wayang Kamasan diperlukannya suatu catatan mengenai seluruh seluk-beluk seni Lukis Wayang Kamasan yang dapat diakses oleh masyarakat dengan mudah. Catatan yang dimaksud ialah sebuah Film Dokumenter Seni Lukis Wayang Kamasan. Nilai lebih dari sebuah film dokumenter yaitu dapat menarik minat audiens untuk peduli terhadap kebudayaan bali, dan juga dapat dijadikan media pembelajaran. Dari segi kuantitas dan kualitas banyak informasi dapat dirangkum ke dalam bentuk film dokumenter, nilai-nilai yang tersirat lebih cepat ditangkap karena adanya kelebihan dari sisi audio dan visual.

\section{KAJIAN TEORI}

A. Sejarah Seni Lukis Wayang kamasan.

Seni lukis wayang kamasan adalah salah satu bentuk karya seni klasik yang berawal pada abad ke-17 dan dianggap penting dalam kebudayaan Bali. Sementara karya seni ini tidak dapat dipisahkan dari nilai keagamaan, terutama nilai ritual. Lukisan wayang tradisional gaya Kamasan merupakan kelanjutan dari tradisi melukis wong-wongan (manusia dengan alam sekitar) pada zaman pra-sejarah hingga masuknya agama Hindu di Bali dan keahlian tersebut mendapatkan kesempatan berkembang dengan baik. Cerita yang dilukis gaya Kamasan banyak yang mengandung unsur seni dan makna filosofis yang diambil dari Ramayana dan Mahabharata, termasuk juga bentuk pawukon dan palelidon. Salah satu contoh warisan lukisan Kamasan telah menghiasi langit-langit di Taman Gili dan Kerthagosa, Semarapura, Klungkung.

Keunikan seni lukis wayang kamasan masih tergolong tradisional, yaitu menggunakan bambu untuk menjadi kuas dan yip (lidi ijuk dari pohon aren) untuk menjadi pena, dan untuk pewarnanya masih menggunakan bahan alami dari tumbuh-tumbuhan.

B. FILM

Film adalah media komunikasi sosial yang terbentuk dari penggabungan dua indra, yakni penglihatan dan pendengaran. Film mempunyai inti atau tema sebuah cerita yang banyak mengungkapkan realita sosial yang terjadi disekitar lingkungan tempat dimana film itu sendiri tumbuh. Film sendiri dapat juga berarti sebuah industri, yang mengutamakan eksistensi dan ketertarikan cerita yang dapat mengajak banyak orang terlibat. Atau cerita singkat yang ditampilkan dalam bentuk gambar dan suara yang dikemas sedemikian rupa dengan permainan kamera, teknik editing, dan skenario yang ada sehingga membuat penonton terpesona. Film secara kolektif sering disebut sinematografi. Sinematografi atau Cinematography terdiri dari dua suku kata cinema dan graphy yang berasal dari Bahasa Yunani, kinema yang berarti gerakan dan graphoo yang berarti menulis. Jadi, sinematografi bisa diartikan menulis dengan gambar yang bergerak. Dalam sinematografi, unsur visual merupakan "alat" utama dalam berkomunikasi. Maka secara kongrit, bahasa yang digunakan dalam sinematografi adalah suatu rangkaian beruntun dari gambar bergerak yang yang dalam pembuatannya memperhatikan seberapa gambar itu ditampilkan, iramanya, dan sebagainya yang kesemuanya merupakan alat komunikasi non-verbal. [5] C. FILM DOKUMENTER

Film dokumenter merupakan sebuah rekaman peristiwa yang diambil dari kejadian dan menyajikan dokumentasi digital dari sebuah fakta atau kenyataan yang sungguh-sungguh terjadi atau otentik, tidak seperti halnya film fiksi. Film dokumenter tidak memilik plot namun memiliki struktur yang umumnya didasarkan oleh tema atau argumen dari sineasnya (orang yang ahli tentang cara dan teknik pembuatan film). [6] 
D. Tipe Film Dokumenter

Tipe film lebih cenderung mengelompok dari pendekatan wujud yang terlihat secara kasat mata serta dapat dirasakan dampaknya oleh penonton, sehingga lebih dekat dengan gaya film seperti unsur mise-en-scene, sinematografi, editing dan suara. Klasifikasi tipe-tipe film dokumenter yaitu (1) Tipe Expository, (2) Tipe Observational, (3) Tipe Interactive, (4) Tipe Reflexive, (5) Tipe Performative, (6) Tipe Poetic.

\section{METODELOGI}

Metodologi penelitian yang digunakan untuk Film Dokumenter Seni Lukis Wayang
Kamasan Desa Kamasan Klungkung Bali adalah metode cyclic strategy. Dalam penelitian ini, metode cyclic strategy akan diimplementasikan ke dalam metode perancangan pembuatan film dokumenter Model Cyclic Strategy atau strategi berputar merupakan sebuah model yang ada kalanya suatu tahap perlu diulang kembali sebelum tahap berikutnya dilanjutkan. Pengulangan tahap ini sering disebut dengan loop. Pengulangan tahap ini dimaksudkan untuk menampung umpan balik (feed back) sebelum tahap berikutnya dilanjutkan. [7]

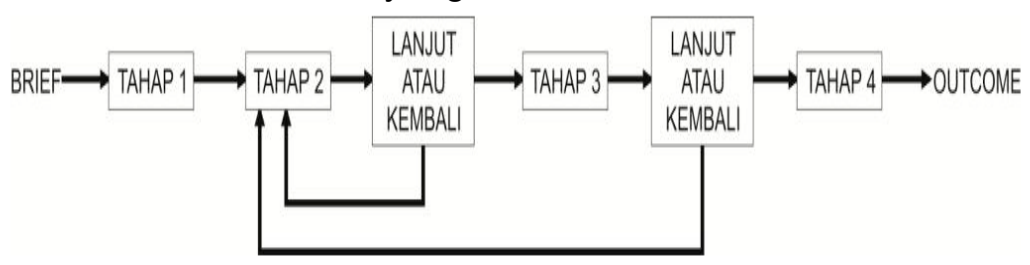

Gambar 1. Tahapan Proses Penelitian

\section{A. Brief}

Tahap brief merupakan tahap pertama dalam metode cyclic strategy dari perancangan Film Dokumenter Seni Lukis Wayang Kamasan. Tahapan brief dibagi menjadi beberapa fase, yaitu:

1. Penawaran Ide

Pada fase ini dilakukan penawaran atau pengajuan ide ke produser atau ke sponsor yang akan bertanggung jawab dalam pembuatan film dokumenter. Pada penelitian dengan judul Film Dokumenter Seni Lukis Wayang Kamasan ini diajukan kepada pihak Jurusan Pendidikan Teknik Informatika, Universitas Pendidikan Ganesha untuk mendapat persetujuan.

\section{Riset Awal}

Setelah ide diterima, maka fase selanjutnya adalah melakukan riset awal berkait dengan Seni Lukis Wayang Kamasan.

B. Tahap 1 (Pengumpulan data dan analisa)

Tahap 1 ini dibagi menjadi beberapa fase, antara lain:

1. Pengumpulan Data

Metode yang digunakan dalam pengumpulan data untuk film dokumenter Seni Lukis Wayang Kamasan adalah metode kualitatif. Teknik pengumpulan data tersebut dijabarkan sebagai berikut : (1) Observasi, (2) Wawancara, (3) Studi Pustaka, (4) Dokumentasi.

2. Analisis

Hasil dari fase pengumpulan data tersebut dianalisis guna mengetahui kebutuhan dalam pembuatan film dokumenter, kelebihan, kekurangan, maupun target audiens film dokumenter. Berikut merupakan analisis yang dibutuhkan dalam pebutan film dokumenter : (1) Analisa Talent, (2) Analisa Lokasi, (3) Analisa alat, (4) Analisa Crew, (5) Analisa SWOT, (6) Analisa STP.

C. Tahap 2 (Pra Produksi

Pada tahap 2 terdapat fase pra produksi. Tahap pra produksi merupakan tahapan persiapan atau perencanaan dalam pembuatan sebuah film. Tahapan ini berguna untuk mengurangi kesalahan dan meminimalisir kurang koordinasinya komunikasi antar personil yang bertugas agar mampu melaksanakan tugasnya masing-masing. Pada tahapan produksi 
dibuat ide cerita, synopsis, skenario dan storyboard.

D. Evaluasi 1

Setelah tahap 2, akan ada pengujian yang bertujuan untuk mengecek kembali apakah semua bagian dalam tahap 1 dan tahap 2 telah terlaksana. Jika ada yang belum terlaksana maka akan dilakukan looping/pengulangan dengan merevisi kembali rancangan film. Sedangkan jika semua telah terlaksana maka akan dilajutkan ke tahap berikutnya.

E. Tahap 3 (Produksi dan Pasca Produksi)

1. Produksi

Pada tahap ini desain film yang berupa ide cerita, sinopsis, storyline, dan storyboard yang sudah dibuat pada tahap pra produksi akan dikembangkan. Dalam tahapan produksi dilakukan beberapa hal, antara lain:

a. Video Production

Pada tahap ini dilakukan pengambilan gambar video, sesuai dengan storyline dan storyboard yang telah dibuat pada tahap desain. Pengambilan gambar film dibagi menjadi beberapa hari. Pengambilan gambar dibagi menjadi tiga jenis, antara lain: (1) pengambilan video narasumber, (2) pengambilan video panorama, (3) pengambilan video Seni Lukis Wayang Kamasan.

b. Audio Production

Pada tahap ini dilakukan pembuatan audio yang akan digunakan pada film. Pembuatan audio dilakukan dengan merekam pengisi suara atau narator yang akan dilakukan editing audio menggunakan aplikasi Adobe Audition Pro CC 2018.

2. Pasca Produksi

Pada tahap ini video dan audio yang telah dibuat pada tahap produksi akan dirapikan dan digabungkan untuk menjadi sebuah film dokumenter. Dalam tahapan pasca produksi dilakukan beberapa hal, antara lain:

a. Editing Film

Pada tahap ini dilakukan editing pada film yang telah dibuat. Editing ini berupa penggabungan seluruh hasil dokumentasi film, pengisian musik latar, perekaman suara narasi yang telah dibuat pada tahap audio production, transisi antar video, penambahan efek animasi, color grading (penyelarasan warna).

b. Editing Audio

Pada editing audio dilakukan DAW (Digital Audio Workstation). Kegiatan utama pada tahap ini ialah proses pembersihan suara-suara yang dirasa menggangu dan tidak diperlukan untuk film ini (noise) yang didapatkan saat pengambilan gambar mempergunakan Audacity dan Reaper sebagai software DAW.

C. Mixing

Setelah tahap editing sudah dilakukan, tahapan selanjutnya adalah mixing. Pada tahap ini dilakukan penggabungan dari video dan audio.

d. Rendering

Pada tahap ini dilakukan render dari film dokumenter Seni Lukis Wayang Kamasan. Rendering film menggunakan format H.264 (MP4). Sedangkan resolusi yang digunakan dalam film dokumenter ini sebesar 1920x108.

F. Evaluasi 2

Tahap ini dilakukan untuk mengetahui apakah film dokumenter Seni Lukis Wayang Kamasan. telah sesuai dengan standar produksi film dokumenter sehingga didapatkan hasil apakah perlu dilakukan revisi kembali atau tidak terhadap film dokumenter ini.

1. Uji Ahli Isi

Uji ahli isi dilakukan untuk mengetahui kesesuaian isi film Seni Lukis Wayang Kamasan, baik dari sejarah maupun tradisinya.

2. Uji Ahli Media

Uji ahli media dilakukan untuk mengetahui apakah film yang dikembangkan siap untuk dipublikasikan atau tidak.

G. Tahap 4 (Mastering)

Tahap 4 merupakan tahapan sebelum film ini di sebarluaskan. Pada tahap 4 ini terdapat fase mastering. Mastering merupakan proses dimana file yang telah dirender dipindahkan kedalam DVD atau media lainya.

H. Outcome

Outcome merupakan tahapan terakhir dari pembuatan film dokumenter ini. Tahap terakhir yaitu publikasi. Produk akhir film 
yang telah dikemas dalam bentuk DVD serta poster siap dipublikasikan.

\section{HASIL DAN PEMBAHASA}

A. HASIL

1. Hasil Tahap Brief

Tahap pertama dilakukan dari perancangan film dokumenter Seni Lukis Wayang Kamasan yaitu, penawaran ide atau topik terhadap jurusan Pendidikan Teknik Informatika. Ide atau topic yang di ajukan telah di setujui pada tanggal 19 Juni 2017 oleh Ketua Jurusan Pendidikan Teknik Informatika. Kemudian dilakukan riset awal berkaitan dengan film dokumenter Seni Lukis Wayang Kamasan pada tanggal 8 februari 2018.

2. Hasil Tahap 1 (Pengumpulan data dan Analisa)

Pada tahap ini dilakukan pengumpulan data menggunakan metode observasi yaitu dengan datang langsung ke Desa Kamasan. Untuk mengetahui lebih dekat dengan Seni Lukis Wayang Kamasan, dilakukan wawancara terhadap Seniman lukis wayang kamasan. Selain itu dilakukan juga pengambilan gambar sebagai dokumentasi terkait Seni Lukis Wayang Kamasan.

Dari hasil pengumpulan data yang di dapatkan kemudian dilakukan beberapa tahapan analisis sebagai berikut :

a. Analisis talent

Analisis talent dilakukan untuk mengetahui siapa saja yang akan terlibat dalam Film dokumenter Seni Lukis Wayang Kamasan. Film dokumenter ini akan melibatkan beberapa narasumber. Narasumber adalah talent yang akan menjelaskan tentang sejarah dan proses dari Seni Lukis Wayang Kamasan. Narasumber-narasumber tersebut, antara lain: (1) Ni Wayan Sri Wedari (Seniman Lukis Wayang kamasan), (2) Ida Bagus Ketut Danendra (Kepala Desa Kamasan)

b. Analisa lokasi

Film dokumenter Seni Lukis Wayang Kamasan akan menggunakan lokasi pengambilan gambar di Desa Kamasan itu sendiri.

c. Analisa Alat

Peralatan yang digunakan dalam pembuatan film dokumenter Seni Lukis Wayang Kamasan Klungkung Bali adalah sebagai berikut.
1. Kamera DSLR Canon $60 \mathrm{D}$

2. Kamera Mirrorless Sony a6000

3. Lensa EF $55 \mathrm{~mm}$ (fix)

4. Drone Dji Phantom

5. Tripod

6. Rode microphone

7. Komputer. Dengan spesifikasi sebagai berikut:
a. Proccesor Intel(R) Core(TM) i5
b. Memory (RAM) 8GB DDR5
c. Harddisk 1TB
d. Msi GTX 720Ti (2GB)
f. DVD/RW

d. Analisis Crew

Dalam pembuatan film dokumenter Seni Lukis Wayang Kamasan ini, peneliti dibantu oleh 9 crew.

e. Analisis SWOT(Strenght, Weakness, Opportunity, Threat)

Adapun hasil analisis SWOT dijabarkan sebagai berikut.

1) Strength (Kekuatan):

a) Kekuatan yang terdapat pada film dokumenter Seni Lukis Wayang Kamasan adalah film dokumenter yang mengangkat sebuah sei lukis bali klasik. b) Film diperkuat dengan penjelasan dari 2 orang narasumber yang mengetahui tentang tradisi ini.

c) Terjalinnya komunikasi yang baik dengan narasumber, sehingga dalam proses pembuatan film ini mendapatkan dukungan penuh dari narasumber.

2) Weakness (Kelemahan):

a) Alat yang digunakan dalam pembuatan film ini juga masih terbilang belum maksimal. b) Keterbatasan jarak serta sulitnya mencari jadwal wawancara terhadap narasumber. c) Keterbatasan biaya produksi film dokumenter ini juga menjadi kelemahan dimana segala sesuatu dalam proses pembuatan film ini seperti transportasi, konsumsi, dan penyewaan alat.

3) Opportunity (Kesempatan):

a) Film ini nantinya akan menjadi media dokumentasi dalam bentuk film dokumenter yang mengangkat Seni Lukis Wayang Kamasan. Selain itu, film ini dapat digunakan untuk edukasi terhadap Seni Lukis Wayang Kamasan. b) Kurangnya media 
sosialisai berbentuk digital yang sangat dibutuhkan oleh Dinas Kebudayaan dan Pariwisatan Kabupaten Klungkung menjadi salah satu peluang atau kesempatan untuk melakukan kerjasama untuk menyebar luaskan film ini ke masyarakat luas serta sebagai arsip instansi tersebut.

4) Threat (Ancaman):

a) Dalam menentukan jadwal pengambilan gambar. Selain itu kendala dengan narasumber dalam pembuatan film dokumenter adalah akibat narasumber sulit dihubungi. Selain itu, pengambilan gambar yang dilakukan lebih banyak di luar ruangan (outdoor) mengakibatkan banyak sekali gangguan seperti perubahan cuaca yang dari cerah tiba-tiba menjadi hujan, serta gangguan seperti di suara kendaraan bermotor (noise)

f. Analisis STP (Segmentation, Targeting, Positioning)

Setelah melakukan analisis SWOT, maka akan dilakukan penetapan target audiens sebagai ketentuan penyebaran film ke masyarakat. Hasil analisis STP, sebagai berikut :

1) Segmentation (Pemilihan)

a) Geografis: Film ini ditujukan untuk semua wilayah yang ada di Indonesia. Sumber data berada di Provinsi Bali dengan target utama masyarakat Bali khususnya para generasi muda.

b) Demografis: Film ini dapat ditonton oleh khalayak umum dibatasan usia 11 tahun keatas, baik kaum laki-laki maupun perempuan dengan segala jenis pekerjaan tanpa ada batasan.

c) Psikografis : Film dokumenter ini dapat ditonton oleh segala lapisan sosial.

2) Targeting (Target)

Target utama penyebaran film adalah masyarakat di sekitar Desa Kamasan serta masyarakat yang ada di seluruh wilayah Bali bahkan tidak menutup kemungkinan sasaran ke luar pulau Bali.

3) Positioning (Penempatan)
Film dokumenter yang mengangkat salah satu budaya yang penuh akan makna dan filosofi di Bali yang dimana masyarakat khususnya generasi muda dan masyarakat awam belum banyak mengetahui secara mendalam makna dari seni lukis wayang kamasan ini.

3. Hasil Tahap 2 (Pra Produksi)

Tahap 2 merupakan tahapan pra produksi. Pada tahap pra produksi terdapat beberapa tahapan yang telah dilakukan, yaitu pembuatan ide cerita, sinopsis, skenario, dan storyboard. Hasil dari tahap pra produksi dijabarkan sebagai berikut.

a. Ide Cerita

Ide cerita merupakan bagian dasar untuk pembuatan sebuah film dokumenter. Ide cerita dari pembuatan film dokumenter Seni Lukis Wayang Kamasan Klungkung Bali dibuat berdasarkan berdasarkan cerita fakta hasil observasi dan wawancara dengan I Nyoman Mandra(alm), Ni Wayan Sri Wedari selaku seniman lukis Wayang Kamasan. Dimana dalam hasil observasi dan wawancara tersebut ditemukan fakta bahwa kurangnya minat generasi muda untuk ikut berperan dalam pelestarian seni lukis Wayang Kamasan. Dalam Film Seni Lukis Wayang Kamasan Klungkung ini diceritakan tentang pengenalan seni lukis Wayang Kamasan, sejarah seni Lukis Wayang Kamasan dan perkembangan seni Lukis Wayang Kamasan hingga sekarang dengan tujuan memperkenalkan kepada masyarakat dengan harapan agar masyarakat khususnya generasi muda memiliki minat untuk mempelajarinya atau setidaknya mau ikut melestarikan seni Lukis Wayang Kamasan ini. Kemasan dalam bentuk film dokumenter dipilih dikarenakan film dokumenter memiliki kelebihan secara audio visual untuk menyajikan informasi dan penyajian informasi akan terlihat lebih interaktif.

b. Sinopsis

Film Dokumenter Seni Lukis Wayang Kamasan Klungkung mengangkat catatan historis Lukisan Wayang Kamasan di Desa Kamasan Klungkung. Seni Lukis Wayang Kamasan adalah salah satu bentuk karya seni klasik yang 
berawal pada abad ke-17 dan dianggap penting dalam kebudayaan Bali. Sementara karya seni ini tidak dapat dipisahkan dari nilai keagamaan, terutama nilai ritual. Cerita yang dilukis gaya Kamasan banyak yang mengandung unsur seni dan makna filosofis yang diambil dari Ramayana dan Mahabharata, termasuk juga bentuk pawukon dan palelidon. Salah satu contoh warisan lukisan Kamasan telah menghiasi langit-langit di Taman Gili dan Kerthagosa, Semarapura, Klungkung.

Pada bagian akhir ditampilkan harapan dari narasumber, terutama seniman seni lukis wayang kamasan yang ingin kegiatan melukis seni lukis wayang kamasan tetap adan dan menjadi lestari.

c. Skenario

Skenario film dokumenter adalah sebuah naskah cerita yang menguraikan urut-urutan adegan, tempat, keadaan, dan dialog, yang disusun dalam konteks struktur dramatik untuk menjadi acuan dalam proses produksi film dokumenter Seni Lukis Wayang Kamasan Klungkung Bali. Skenario film dokumenter Seni Lukis Wayang Kamasan Klungkung Bali dapat dilihat pada lampiran.

d. Storyboard

Storyboard film dokumenter Seni Lukis Wayang Kamasan Klungkung Bali merupakan gambaran lebih jelas terhadap skenario yang telah dibuat. Cerita yang tergambarkan pada storyboard sama dengan cerita yang disampaikan pada skenario film dokumenter Seni Lukis Wayang Kamasan Klungkung Bali.

4. Hasil Evaluasi 1

Tahap evaluasi 1 dilakukan untuk mengetahui kesiapan pada tahap 1 dan tahap 2. Tahap evaluasi ini dilakukan oleh pembuat film menggunakan chek list.

5. Hasil Tahap 3 (Produksi dan Pasca Produksi)

Tahap 3 terdiri dari dua fase yaitu tahap produksi dan tahap pasca produksi. Hasil dari tahap 3, yaitu :

\section{1) Produksi}

Tahap produksi dilakukan proses pengambilan gambar. Hasil tahapan produksi dapat dilihat pada Gambar 4.1, Gambar 4.2.

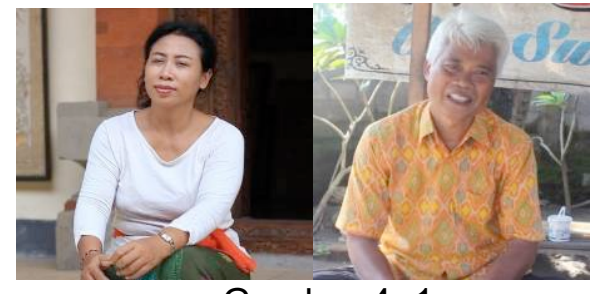

Gambar 4. 1.

Pengambilan Gambar Narasumber

2) Pasca Produksi

Pada fase pasca produksi, hasil dari pengambilan gambar sebelumnya akan melalui tahapan editing. Pada pasca produksi akan dilakukan editing, mixing, dan rendering.

a. Proses editing

Proses editing video dilakukan menggunakan software Adobe Premiere Pro CC 2018 dan untuk editing audio menggunakan software Adobe Audition CC. Dalam tahapan editing video juga dilakukan proses color grading untuk mengatur penyesuaian warna dalam video. Selain editing video, yang perlu dilakukan dalam fase pasca produksi ini yaitu tahapan editing audio.

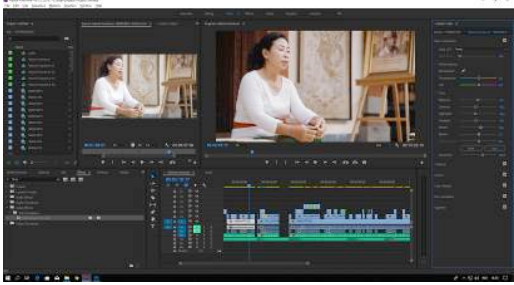

Gambar 4.2

Proses Color Grading pada Adobe Premiere CC 2018

b. Mixing

Tahap mixing dilakukan menggunakan software Adobe Premiere Pro CC 2018.

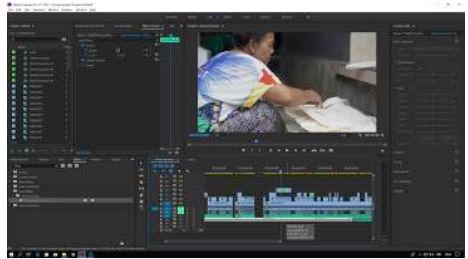

Gamabr 4.3

Preoses Mixing

c. Rendering

Proses rendering menggunakan software Adobe Premiere Pro CC 2018. File akan diubah sesuai dengan format yang diinginkan. 


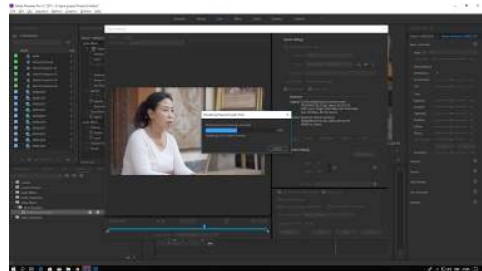

Gambar 4. 7.

Proses rendering

\section{Evaluasi 2}

a. Pengujian Ahli Isi

Berdasarkan rekaptulasi penilaian dari masing-masing penguji ahli isi dapat disimpulkan bawa rata-rata persentase keseluruahan adalah $89,99 \%$. Selanjutnya rata-rata persentase tersebut bila dikonversikan ke dalam tabel konversi berada dalam kualifikasi baik.

b. Pengujian Ahli Media

Berdasarkan rekaptulasi penilaian dari masing-masing penguji ahli Media dapat disimpulkan bawa rata-rata persentase keseluruahan adalah $88.58 \%$. Selanjutnya rata-rata persentase tersebut bila dikonversikan ke dalam tabel konversi berada dalam kualifikasi baik.

7. Hasil Tahap 4 (Mastering)

Pada tahap 4 dilakukan burning dan desain. Hasil tahap ini, yaitu :

1. Burning

Burning telah dilakukan dimana hasil tahap ini yaitu sebuah DVD dengan resolusi 1920 x 1080 dengan fomat H.264 yang siap untuk dipublikasikan.

2. Hasil Desain

1) Desain Kepingan DVD

Kepingan DVD telah didesain sesuai dengan rancangan yang telah ditentukan. Hasil desain kepingan DVD film documenter Seni Lukis Wayang Kamasan.

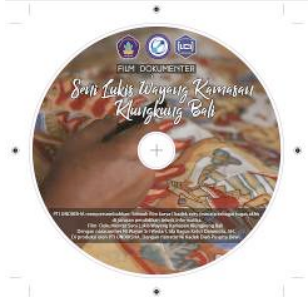

Gambar 4.8.

Desain Kepingan DVD

2) Hasil Desain Poster

Poster telah didesain sesuai dengan rancangan yang telah ditentukan. Hasil desain poster film dokumenter Seni
Lukis Wayang Kamasan dapat dilihat pada Gambar 4.9.

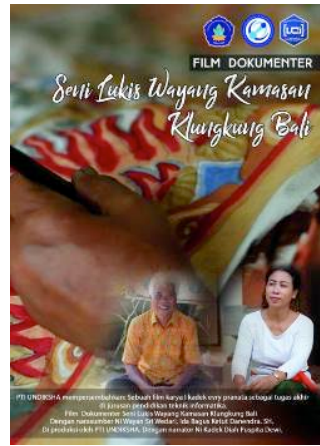

Gambar 4.9.

Desain Poster

3) Hasil Desain Cover DVD

Cover DVD telah didesain sesuai dengan rancangan yang telah ditentukan. Hasil desain cover DVD film dokumenter Seni Lukis Wayang Kamasan dapat dilihat pada Gambar 4.10 .

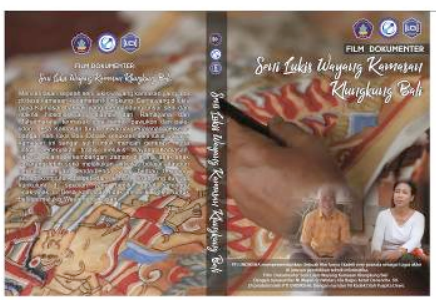

Gambar 4.10

8. Hasil Outcome

\section{Desain Sampul DVD}

Setelah film selesai di kemas maka film siap di publikasikan sesuai dengan target yang telah ditentukan sebelumnya.

\section{B. HASIL UJI RESPONDEN}

Uji Respon Pengguna dilakukan untuk mengetahui tanggapan penonton film dokumenter Seni Lukis Wayang Kamasan.Uji respon pengguna dilakukan dengan cara menyebarkan angket kepada 30 orang dengan rentangan usia dari anakanak sampai tua setelah menonton film dokumenter Seni Lukis Wayang Kamasan didapatkan persentase sebanyak $91.18 \%$ yang berarti hasil respon dalam rentangan sangat baik.

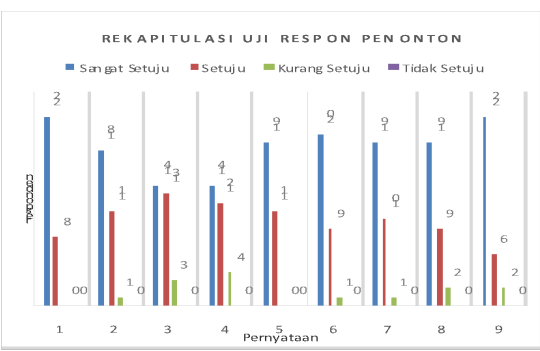




\section{PEMBAHASAN}

Sesuai dengan pemaparan hasil film dokmuenter Seni Lukis Wayang Kamasan Klungkung Bali, berikut ini diuraikan pembahasan film dokumenter Seni Lukis Wayang Kamasan Klungkung Bali. Pembahasan difokuskan pada implementasi dan hasil respon penonton film dokumenter Seni Lukis Wayang Kamasan Klungkung Bali.

Film dokumenter Seni Lukis Wayang Kamasan Klungkung Bali menganut jenis film dokumenter sejarah dan ilmu pengetahuan, Dalam film ini tipe film dokumenter yang diusung yaitu tipe interactive, di mana nantinya akan ada beberapa tokoh yang memperkenalkan Desa Kamasan, memperkenalkan seni lukis wayang kamasan, menyampaikan asal usul dari seni lukis wayang kamasan dan perkembangannya hingga sekarang. Semua bagian tersebut akan ditampilkan lewat wawancara langsung dengan berbagai narasumber seperti, beberapa tokoh kepala desa dan Seniman Desa Kamasan.

Berdasarkan film dokumenter Seni Lukis Wayang Kamasan Klungkung Bali menggunakan modelcyclic strategy. Model cyclic strategy memilki delapan tahapan, antara lain: brief, tahap 1, tahap 2, evaluasi 1 , tahap 3, evaluasi 2, tahap 4 dan outcome. Pada tahap brief dilakukanmenganalisis permasalahan yang ada dan pengajuan ide atau topik kepada ketua Jurusan Pendidikan Teknik Informatika. Setelah ide disetujui akan dilanjutkan ke tahap 1 yaitu melakukan pengumpulan data dan analisis kebutuhan. Pada tahap pengumpulan data, dilakukan pencarian informasi kepada orang-orang yang mengetahui Seni Lukis Wayang Kamasan Klungkung. Setelah semua informasi terkumpul, data yang didapat kemudian akan dianalisis. Dalam analisis ini dilakukan analisis talent, analisis lokasi, analisis alat, analisis crew, analisi SWOT dan analisis STP.

Pada tahap 2 dilakukan tahapan pra produksi film yang meliputi penentuan ide cerita, sinopsis, skenario dan storyboard. Ide cerita diperoleh dari hasil wawancara terhadap narasumber yang sudah ditentukan. Selanjutnya pembuatan sinopsis yang dibuat berdasarkan ide cerita. Setelah pembuatan sinopsis dilanjutkan dengan pembuatan skenario dan storyboard sebagai acuan dalam proses produksi.Selanjutnya dilakukan evaluasi 1 untuk menguji tahap 1 dan tahap 2. Pada tahap ini dilakukan dengan checklist, uji ahli isi, dan uji ahli media. Pemeriksaan checklist dilakukan dengan cara mencentang hal-hal yang telah dilakukan.

Tahap 3 adalah tahapan produksi dan pasca produksi film dokumenter Seni Lukis Wayang Kamasan Klungkung Bali. Pada tahapan produksi dilakukan proses pengambilan gambar (shooting) di lokasilokasi yang telah ditentukan dan pembuatan ilustrasi. Setelah proses pengambilan gambar selesai kemudian dilakukan tahapan pasca produksi film dokumenter. Di mana dalam tahapan ini terdiri dari proses editing film dokumenter, mixing, dan rendering.

Setelah tahap 3 selesai dilaksanakan, maka dilakukan evaluasi yang kedua. Berbeda dengan evaluasi tahap pertama, evaluasi tahap kedua ini dilakukan untuk menguji film dokumenter Seni Lukis Wayang Kamasan Klungkung Bali yang telah selesai dibuat. Uji ahli isi dilakukan oleh dua orang ahli dengan instrumen angket, diperoleh hasil rata-rata persentase penilaian yang didapat yaitu sebesar 89,99\% masuk dalam kategori Sangat Baik.Sedangkan untuk uji ahli media dilakukan oleh dua orang ahli yang berkompeten di bidangnya. Uji ahli media menggunakan instrumen angket dengan cara mencentang jawaban yang dianggap sesuai, diperoleh hasil rata-rata persentase penilaian yang didapat yaitu sebesar $85,58 \%$ masuk dalam kategori Sangat Baik. Hasil Sangat Baik ini diperoleh karena peneliti mengimplementasikan teori tentang Framing (Type Of Shot), Camera Angles, Pergerakan Kamera, Komposisi, Lighting, Audio, Music, Efek Suara dan Ambiance. Namun terdapat beberapa kendala yang menyebabkan hasil kurang maksimal yaitu pemilihan jenis shot kurang bervariasi, penggunaan effect film belum maksimal, kualitas hasil gambar kurang maksimal dikarenakan keterbatasan alat pada saat pengambilan gambar, pemilihan jenis font kurang bervariatif, pencahayaan belum maksimal, masih terdapat shadows yang mengakibatkan hasil kurang maksimal, footige yang masih kurang, pengambilan sudut gambar dan pergerakan kamera 
kurang bervariatif, suara narasumber masih terdapat noise.

Pada tahap 4 dilakukan proses mastering file yang sudah di-render, kemudian dikemas dalam bentuk DVD dan dapat dipublikasikan. Dilanjutkan ke tahap outcome yang merupakan tahap terakhir pada pembuatan film dokumenter Seni Lukis Wayang Kamasan Klungkung Bali. Setelah semua tahap dilalui, dilakukan uji respon penonton. Pengujian ini menggunakan angket skala lima, uji respon penonton diperoleh hasil rata-rata persentase penilaian yang didapat yaitu sebesar 91.18\%. Hasil Sangat Baik ini diperoleh karena peneliti mengimplementasikan teori tentang Struktur Film Dokumenter, UnsurUnsur Pendukung Komposisi, Unsur-Unsur Suara.Pada uji respon penonton film dokumenter ini peneliti melakukan pengujian terhadap 30 orang responden yang diambil secara acak.

Berdasarkan pembuatan film dokumenter Seni Lukis Wayang Kamasan Klungkung Bali tidak lepas dari berbagai kendala. Adapun kendala-kendala yang dihadapi salah satunya yaitu menentukkan jadwal untuk shooting wawancara dengan narasumber, di mana beberapa narasumber memiliki kesibukkan yang tidak sedikit sehingga penulis agak kesulitan dalam menentukkan jadwal untuk shooting, namun kendala tersebut dapat teratasi dengan menjalin komunikasi yang baik dengan narasumber sehingga jadwal shooting bisa dikoordinasikan dengan baik.

Pengambilan gambar, penulis juga mengalami beberapa kendala seperti banyaknya suara noise yang masuk karena kebanyakan pengambilan gambar dilakukan di luar ruangan. Namun dengan memanfaatkan software Adobe Audition CS 6 untuk mengurangi noise suara, kendala tersebut dapat diatasi. Selain itu penulis juga mendapatkan kendala dalam hal mengumpulkan crew dalam proses shooting, namun dapat diatasi dengan memaksimalkan peralatan yang ada. Dalam teknik editing video juga terdapat beberapa kendala yaitu kesulitan dalam mengatur resolusi warna video, ini dikarenakan pada saat pengambilan gambar menggunakan kamera berbeda jenis sehingga ketajaman warna yang dihasilkan dari masing-masing kamera tidak sama. Namun kendala tersebut dapat diatasi dengan cara menambahkan effect Fast Color Corrector serta mengatur Brightness \& Contrast pada masing-masing video.

Hasil penelitian yang relevan dengan penelitian film dokumenter ini yaitu Film dokumenter yang berjudul "Film Dokumenter Genggong (Sebuah Instrumen Musik Kuno)" dibuat oleh I Made Dedik Suardika, Gede Saindra Santyadiputra, Gede Aditra Pradnyana, (2017) menggunakan metode Cyclic Strategy. Film dokumenter ini bertujuan agar keberadaan alat musik genggong di Bali semakin dikenal, serta dapat dijadikan sebuah media informasi sekaligus sebagai media pelestarian terhadap instrumen musik genggong. Respon pengguna terhadap film dokumenter genggong dapat dikategorikan sangat positif dengan persentase $90.04 \%$. [8]

\section{KESIMPULAN DAN SARAN}

A. SIMPULAN

Berdasarkan hasil penelitian dan pembahasan film dokumenter Seni Lukis Wayang Kamasan Klungkung Bali, maka penulis dapat menarik kesimpulan sebagai berikut.

1. Perancangan film dokumenter Seni Lukis Wayang Kamasan Klungkung Bali telah berhasil dilaksanakan dengan menggunakan model cyclic strategy dan menggunakan tahapan produksi film yaitu pra produksi, produksi dan pasca produksi. Film dokumenter Seni Lukis Wayang Kamasan Klungkung Bali menganut jenis film dokumenter sejarah, investigasi dan bertipe interactive. Sedangkan pengimplementasian film dokumenter Seni Lukis Wayang Kamasan Klungkung Bali telah sesuai pada rancangan yang telah dibuat sebelumnya dengan tambahan. Film dokumenter Seni Lukis Wayang Kamasan Klungkung Bali diimplementasikan menggunakan aplikasi Adobe Premiere Pro CC 2017, Adobe Effect CS 6 untuk penambahan effect, sedangkan Adobe Audition CS 6 untuk audio. Memperoleh hasil dari uji ahli isi dan uji ahli media yang 
dikategorikan ke dalam pencapaian sangat baik.

2. Berdasarkan hasil uji respon film dokumenter Seni Lukis Wayang Kamasan Klungkung Bali terhadap 30 responden yang berasal dari masyarakat terutama generasi muda yang ada di, diperoleh persentase keseluruhan sebanyak $91.18 \%$. Hasil yang diperoleh ini dikategorikan ke dalam pencapaian sangat baik.

B. SARAN

Saran bagi para penliti yang akan meneliti film dokumenter selanjutnya antara lain :

1. Dalam proses perencanaan pembuatan film dokumenter dibutuhkan perencanaan yang matang sehingga penulis menyarankan untuk peneliti lain yang akan membuat film dokumenter untuk menggali lebih dalam informasi dan mempertimbangkan kondisi lain yang tidak terduga. Karena film dokumenter adalah film yang menyampaikan informasi yang benar benar terjadi atau faktual. Jadi diharapkan untuk siap dalam segala situasi termasuk dalam kelengkapan rekaman

2. Untuk masyarakat Bali khususnya generasi muda saat ini, agar tetap menjaga seni dan tradisi yang terdapat di daerahnya masing-masing, baik itu dengan membuat film dokumenter atau yang lainnya, sehingga tidak mengalami kepunahan dan bisa disaksikan oleh generasi berikutnya.

\section{REFERENSI}

[1]. Mudana, I. W., \& Mudana, I. W. (2015). Transformasi Seni Lukis Wayang Kamasan pada Era Postmodern di Klungkung, Bali(Doctoral dissertation, Universitas Udayana). Mudana, I.

[2]. W., \& Ribek, P. K. (2017). Komodifikasi Seni Lukis Wayang Kamasan Sebagai Produk Industri Kreatif Penunjang Pariwisata. Mudra Jurnal Seni Budaya, 32(1).

[3]. Suyasa, I. N. (2016). Transformasi Penciptaan Seni Lukis Bali. Brikolase: Jurnal Kajian Teori, Praktik dan Wacana Seni Budaya Rupa, 2(2).
[4]. Rikarno, R. (2015). Film Dokumenter Sebagai Sumber Belajar Siswa. Ekspresi Seni, 17(1), 129-149.

[5]. Narayana, I. P. A., Santyadiputra, G. S., ST, M. C., Pradnyana, G. A., Kom, S., \& Kom, M. (2017). Film Dokumenter Tok Lait Kancing: Sebuah Warisan Karakter Budaya Bangsa. Kumpulan Artikel Mahasiswa Pendidikan Teknik Informatika (ISSN: 2252-9063), 6(1).

[6]. Herdian, D. I., Triyono, R. A., S Kom, M. M., Kusanti, J., \& S Kom, M. (2015). Produksi Video Dokumenter Museum Radyapustaka Di Surakarta Dengan Mengaplikasikan Teknik Time Lapse. EPUB-MULTIMEDIA, 1(1).

[7]. Sarwono, J., \& Lubis, H. (2007). Metode riset untuk desain komunikasi visual. Yogyakarta: Andi.

[8]. Santyadiputra, G. S., Pradnyana, G. A., \& Suardika, I. M. D. (2017). Film Dokumenter Genggong "Sebuah Instrumen Musik Kuno". Jurnal Nasional Pendidikan Teknik Informatika (JANAPATI), 6(1), 60-69. 